\title{
An Effective Learning of Exposition Text Writing with Sequential Jigsaw Method
}

\author{
Yakub Nasucha ${ }^{1}$, Haris Mudjiman ${ }^{2}$ \\ ${ }^{1}$ Uiversitas Muhammadiyah Surakarta, Faculty of Teacher Trining and Education, Indonesian Education Department, \\ A. Yani St. Pabelan, Tromol Pos 1, Pabelan Surakarta 57102 Indonesia \\ ${ }^{2}$ Universitas Sebelas Maret Surakarta, Faculty of Teacher Training and Education, \\ Ir. Sutami St. No. 36 A, Kentingan, Central Java 57126 Indonesia
}

\begin{abstract}
The study aims to describe an effective learning of exposition writing with sequential jigsaw method at SMA Negeri State Senior High School, Karanganyar regency, Central Java, Indonesia. A teacher-centered learning makes students uncreative and silent participants. In addition, the teachers always employ a conventional method so that it makes the interaction between teachers and students ineffective and boring. With a cooperative method such as jigsaw as a student-centered, in contrast, it seems that there is a closer interaction between teachers and students so that it makes the students feel comfortable. The finding of the study shows that a learning method of jigsaw method called Jigsaw Innovation relates to producing a material of exposition text. The sequential activities include six stages: (1) conditioning, (2) operating/writing sequentially, (3) discussing, (4) presenting, (5) writing independently, and (6) scoring. The results of the study state that the learning method of sequential jigsaw makes the students more active, creative, and effective than the conventional one. It is indicated with $t$-test where a value of t-count is higher than t-table $(5,529>1,645)$.
\end{abstract}

Keywords: learning, jigsaw, effective, sequential writing.

\section{Introduction}

A teacher-centered learning is said to be uncreative. It makes teachers tend to use a lecture method in a learning process so that it causes students to be silent participants and teachers play a more active role, on the other hand. Therefore, the interaction between teachers and students result in an obvious barrier and there is no inner relation between them. Omatseye (2007) suggests "The traditional know method of teaching in tertiary institutions is the lecture method. In this method, the lecturer has a body of knowledge to communicate to his students who are more or less silent participants. In effect, there is an obvious gulf or barrier between the lecturer and his students". A conventional learning is said to be less applicable or effective than a cooperative one. The result of the research by Chalmers and Fuller [1] states "Students in such integrated programmes used learning strategies more effectively and achieved better results than students who were taught in the conventional way."

However, a teacher-centered learning with a lecture method is not always said to be ineffective, but it reflects a positive aspect. A teacher serves as a controller for a class management so that students will be oriented and wellorganized. Arends [2] suggests a teacher-centered learning is that it is a teacher who manages a learning so that a class learning will be well-structured. Joyce et al [3] state that a teacher-centered learning is similar to direct learning, or called direct instruction. Furthermore, Joyce et al. suggest that a direct instruction reflects some advantages: academic focus, control of teachers, high expectation of student development, time management system, and neutral atmosphere of time. Employing a any learning method is inseparable to a lecture one because it begins a cooperative learning.
A student-centered leaning by discussing actual cases is stated to be better and more innovative. Such a leaning always bases on a cooperative learning because it is a teacher who serves as a key person and facilitator. It aims to make students more active and prevent teachers from dominating the class. According to Andayani [4], a cooperative learning is a sequence of activities by students in given groups to achieve a leaning objective. In other words, it emphasizes on developing the collaboration among the students. Westwood [5] suggest "Student-centred methods are deemed best practice in situations where the teaching objectives for the lesson include acquisition of independent study skills, greater student autonomy, working collaboratively with others, the construction of knowledge from firsthand experience, and the application of basic academic skills for authentic purpose." Kadir at.al [6] state "cooperative learning strategy created an environment that promoted discussion among group members. Students had the opportunity to exchange ideas and to express their views when they were working in groups."

One of the models of Indonesian learning is a cooperative learning, i.e., a learning of exposition text writing with jigsaw method. It is very effective for the learning. It is applied with the distribution of the same texts by teachers to all students in a group. The texts provided by the teachers, then, are discussed by each student. Nevertheless, the development of the jigsaw method is oriented to an applied orientation, i.e., a result of exposition text is a sequential writing by each student in groups. Thus, the sentences in an exposition text are sequentially written by each student. Each student will think that he or she writes a full text and is responsible for it in a group. A learning of sequential exposition text writing was employed to the students of SMA Negeri State Senior High School, Karanganyar regency, Central Java, Indonesia. 


\section{International Journal of Science and Research (IJSR) \\ ISSN (Online): 2319-7064}

Index Copernicus Value (2013): 6.14 | Impact Factor (2014): 5.611

\section{Literature Review}

The term text is a language form and essential in a communication process. According to Achmad and Abdullah [7], text is essentially a language form written in a discourse. Beaugrande and Dressler [8] suggest "a communicative occurrence which meets seven standars of textuality. The text must meet these seven criteria or standards: (1) cohesion (the relation of grammatical text components and form), (2) coherence (integrated meaning configuration, (3) intentionality (a first speaker's great intention to message and objective, (4) acceptability (a second speaker's acceptability to the intention, (5) informativity (easily readable message), (6) situationality (event or situation factor), and (7) intertextuality (useful factor dependent on another text. Brown and Yule [9] states that text is a communicative event or situation. In other words, text is a language event in a communication process. The interaction of humans in a communication process will happen because they mutually need a variety of different activities so that they will also produce different texts such as narration, description, argumentation, and exposition.

According to Mahsun [10], an exposition text contains a personal idea or opinion. Keraf [11] suggests that an exposition text aims at conveying description or information. The exposition text expresses a written idea or opinion or something that is necessary to convey to the readers. In this text, the relation of first paragraph, second paragraph, and the next paragraphs must mutually cohere in form and meaning to convey the content contained in a text

A fundamental learning of exposition text writing with jigsaw method is a cooperative as a substantial model. A learning process that produces a sequential exposition text writing with jigsaw model is very effective. It is based on an effective learning dependent on an interaction process between teachers and students. Bulger [12] shows "Teaching effectiveness is dependent upon the interaction between the instructor's subjec-matter knowledge and teaching (pedagogical) ability". The successfulness in learning is dependent on the teachers who are able to implement a learning method, technique, or strategy. It means that a method, technique, or strategy will work effectively if it is employed by teachers who have a learning skill. Whatever a method, technique, or strategy is, it is a teacher who plays a role in achieve a learning objective.

Knapp and Watkins (in Mahsun, [10]), a exposition text learning covers the following stages: (1) modeling, (2) cooperation for text development, and (3) independent text development. In the cooperation, however, a text development will be running sequentially. So, a developed and analyzed exposition text is sequentially a result of a group's work.

\section{Research Method}

Based on the purpose of the research producing a learning model, the study is categorized as Research and Development. In particular, it aims to produce a learning model of exposition text writing. Gall and Borg [13] suggest "Educational $R$ \& $D$ is an industry-based development model in which the findings of the research are used to design new product and procedures, which then are systematically field-tested, evaluated, and refined until they meet specified criteria of effectiveness, quality, or similar standard". According to Sugiyono [14], a research and development method is used for producing a given work as well as evaluating its effectiveness. Thus, it is necessary to include the stages of the research: (1) introductory, (2) development, and (3) assessment.

\subsection{Introductory Stage}

In the introductory stage, a strategy is a descriptiveexplanative study. It means that it analyzes a learning model of exposition text writing that has been employed by the Indonesian teachers at SMA Negeri State Senior School, Karanganyar regency, Central Java, Indonesia. Based on the observation, they have used a direct or conventional method. The data were collected with an observation and in-depth interview technique. The instruments of the data collection were (1) the tests by the students who have taken a learning of exposition text writing, (2) the questionnaires by teachers and students as a subject of the research, and (3) the document analysis of the tests and scores. The data were analyzed with an interactive model, including data collection, data analysis, and conclusion.

\subsection{Model Development Stage}

The model development stage aims at (1) developing a learning model draft of exposition text writing, (2) reviewing it, and (3) completing it. Then, the stage includes a workshop activity for constructing a model and simulating a learning activity of exposition text writing to the teachers. Therefore, the mechanism of a learning development of exposition text writing with jigsaw model comprises (1) the test of model draft, (2) monitoring and evaluation, and (3) model review. The data of the study were the teachers and students' responses with in-depth interview and questionnaires. The data analysis used a content analysis.

\subsection{Model Assesment Stage}

The model assessment stage aims at evaluating an effective learning model of exposition text writing with sequential jigsaw method. The research employed an experiment method at two State Senior Schools. It is intended to see the comparison of the subject results and model with the model before assessment. According to Sugiyono [14], an experiment research is a research method for exploring a given treatment influence on another in a controlled condition. Sugiyono [14] suggests the use of experiment design is the Intact - Group Comparison. The design of the experiment consists of two groups: one group at SMA Negeri 1 State Senior High School, Karanganyar regency for experiment with getting any treatment and the other group at SMA Negeri 2 State Senior High School, Karanganyar regency, as a control class not getting any treatment.

The design of the learning model includes (1) formulating a

\section{Volume 5 Issue 2, February 2016}




\section{International Journal of Science and Research (IJSR) \\ ISSN (Online): 2319-7064 \\ Index Copernicus Value (2013): 6.14 | Impact Factor (2014): 5.611}

reviewed model, (2) assessing a learning model development, (3) analyzing the result, and (4) drawing a conclusion. The technique of the data collection in the model assessment stage is giving the tests to the students. The data analysis used $t$-test, i.e., comparing the results of experiment and control groups. The product of the research is a learning model of exposition text writing with sequential jigsaw method

\section{Result}

The results of the research state the learning condition of exposition text writing and its need level. In terms of the text learning condition, it is found that there are two things: the use of a method in text learning and a kind of text as an instructional material. The results state that the use of the method in the learning is greatly varied. However, the most frequently used method is the inquiry approach and lecture method. Thus, the learning of exposition text writing at SMA Negeri State Senior High School, Karanganyar regency has not completely used an innovative method as stated in a cooperative learning method. It is due to the problem with the limited length of time and its use if only necessary.

Frequently, the instructional materials are the exposition texts; the narration texts are the most difficult; and the explanation texts are the easiest. The teachers greatly need an innovative method, for example, jigsaw method because it can makes the students run interactively and more systematically. In addition, they can understand a concept easily, the method varies, the students' successfulness will be higher, and they can collaborate with others and help one another. Unfortunately, there have not been teachers who use a sequential writing model for producing an exposition text.

Table 1: Control Group

\begin{tabular}{|c|c|c|c|c|c|c|c|c|c|c|c|}
\hline$*$ & \multicolumn{3}{|c|}{ EXPERIMENT GROUP } & $*$ & \multicolumn{5}{|c|}{ CONTROL GROUP } \\
\hline No & R & A & B & C & $\sum$ & No & R & A & B & C & $\Sigma$ \\
\hline 1 & 01 & 2 & 3 & 3 & 8 & 1 & 01 & 2 & 3 & 1 & 6 \\
\hline 2 & 02 & 2 & 3 & 3 & 8 & 2 & 02 & 2 & 2 & 1 & 5 \\
\hline 3 & 03 & 2 & 4 & 4 & 10 & 3 & 03 & 3 & 3 & 1 & 7 \\
\hline 4 & 04 & 3 & 3 & 2 & 8 & 4 & 04 & 1 & 2 & 2 & 5 \\
\hline 5 & 05 & 2 & 3 & 3 & 8 & 5 & 05 & 1 & 3 & 1 & 5 \\
\hline 6 & 06 & 2 & 3 & 3 & 8 & 6 & 06 & 1 & 2 & 2 & 5 \\
\hline 7 & 07 & 2 & 4 & 3 & 9 & 7 & 07 & 1 & 2 & 1 & 4 \\
\hline 8 & 08 & 2 & 4 & 4 & 10 & 8 & 08 & 1 & 2 & 2 & 5 \\
\hline 9 & 09 & 2 & 4 & 4 & 10 & 9 & 09 & 1 & 3 & 1 & 5 \\
\hline 10 & 10 & 3 & 4 & 4 & 11 & 10 & 10 & 2 & 2 & 2 & 6 \\
\hline 11 & 11 & 2 & 3 & 4 & 9 & 11 & 11 & 1 & 3 & 1 & 5 \\
\hline 12 & 12 & 2 & 3 & 3 & 8 & 12 & 12 & 2 & 2 & 2 & 6 \\
\hline 13 & 13 & 2 & 4 & 4 & 18 & 13 & 13 & 2 & 2 & 1 & 5 \\
\hline 14 & 14 & 2 & 4 & 4 & 10 & 14 & 14 & 2 & 2 & 1 & 5 \\
\hline 15 & 15 & 2 & 4 & 4 & 10 & 15 & 15 & 2 & 2 & 1 & 5 \\
\hline 16 & 16 & 2 & 4 & 3 & 9 & 16 & 16 & 1 & 1 & 1 & 3 \\
\hline 17 & 17 & 3 & 4 & 4 & 11 & 17 & 17 & 1 & 3 & 1 & 5 \\
\hline 18 & 18 & 2 & 4 & 3 & 9 & 18 & 18 & 2 & 3 & 2 & 7 \\
\hline 19 & 19 & 2 & 3 & 2 & 7 & 19 & 19 & 2 & 2 & 2 & 6 \\
\hline 20 & 20 & 2 & 4 & 4 & 10 & 20 & 20 & 1 & 4 & 1 & 6 \\
\hline 21 & 21 & 3 & 3 & 3 & 9 & 21 & 21 & 1 & 2 & 1 & 4 \\
\hline 22 & 22 & 2 & 3 & 3 & 8 & 22 & 22 & 1 & 4 & 1 & 6 \\
\hline 23 & 23 & 3 & 3 & 4 & 10 & 23 & 23 & 1 & 4 & 2 & 7 \\
\hline 24 & 24 & 2 & 3 & 3 & 8 & 24 & 24 & 1 & 3 & 1 & 5 \\
\hline 25 & 25 & 4 & 3 & 4 & 11 & 25 & 25 & 1 & 3 & 3 & 7 \\
\hline & & 57 & 87 & 85 & 229 & $*$ & & 36 & 64 & 35 & 135 \\
\hline
\end{tabular}

The result of the study shows that the learning of exposition text writing with sequential jigsaw method can work effectively. It is based on the comparison with a conventional method where an experiment group used a jigsaw and a control group used a conventional method. The experiment group is higher than the control group with three indicators: (1) an exposition text material understanding (Code A), (2) students' achievements (Code B), and (3) creativity in exposition text writing (Code $\mathrm{C}$ ). The Code $R$ is the number of the respondents (see Table).

- Ideal score for each item of instrument is $4 \times 1 \times 25=100$

(where 4 is the highest score, 1 is one indicator, and 25 is the amount of the respondents).

- Ideal score for each item of instrument is 4 × $3 \times 25=300$ (where 4 is the highest score, 1 is three indicators, and 25 is the amount of the respondents).

\subsection{Experiment Group Counting}

Overall, it is counted as follows: A $(57)+\mathrm{B}(87)+\mathrm{C}(85)=$ 229. The result is $229^{\circ}: 300=0.76$ or $76 \%$. Thus, an effective learning of exposition text writing with sequential jigsaw method achieves $76 \%$.

\subsection{Control Group Counting}

Overall, it is counted as follows: A (36) + B (64) + C (35) $=$ 135. The result is $135: 300=0.45$ or $45 \%$. Thus, an effective learning of exposition text writing with sequential jigsaw method achieves $45 \%$.

Based on the comparison of the result between the experiment and control groups, it can be seen that the experiment group is higher $(76 \%)$ than the control one $(45 \%)$. To see the significant difference in the uses of the learning method of exposition text writing with sequential jigsaw method and conventional one, then, it is necessary to test with $t$-test correlating as a hypothesis test. It is essential because the test is a scientific assumption based on an academic theory of the sample size or population. This is relevant to Budiyono [15], stating that a hypothesis is a statement or assumption of the size (for example: mean or variant) at one or more populations. Furthermore, Budiyono [15] suggest that a null hypothesis is a hypothesis meaning that there is no difference or no correlation. In contrast, an alternative hypothesis is a hypothesis meaning that there is difference or correlation. The null hypothesis is represented with $\mathbf{H}_{\mathbf{0}}$ and alternative hypothesis with $\mathbf{H}_{\mathbf{1}}$ or $\mathbf{H}_{\mathbf{A}}$. The rejected null hypothesis causes the confirmed alternative hypothesis while the confirmed null hypothesis causes the rejected alternative hypothesis. The hypotheses of the research are $\mathbf{H}_{\mathbf{0}}$ : the learning of exposition text writing with sequential jigsaw method, stating that the jigsaw method is more ineffective than conventional one and $\mathbf{H}_{\mathbf{1}}$ : the learning of exposition text writing with sequential jigsaw method, stating that the jigsaw is more effective than conventional method). 


\section{International Journal of Science and Research (IJSR) \\ ISSN (Online): 2319-7064}

Index Copernicus Value (2013): 6.14 | Impact Factor (2014): 5.611

Table 2: Experiment group $\left(\mathrm{X}_{1}\right)$ and Control group $\left(\mathrm{X}_{2}\right)$

\begin{tabular}{|c|c|c|c|c|c|}
\hline No & $\mathrm{X}_{1}$ & $\mathrm{X}_{2}$ & No & $\mathrm{X}_{1}$ & $\mathrm{X}_{2}$ \\
\hline 1 & 8 & 6 & 14 & 10 & 5 \\
\hline 2 & 8 & 5 & 15 & 10 & 5 \\
\hline 3 & 10 & 7 & 16 & 9 & 3 \\
\hline 4 & 8 & 5 & 17 & 11 & 5 \\
\hline 5 & 8 & 5 & 18 & 9 & 7 \\
\hline 6 & 8 & 5 & 19 & 7 & 6 \\
\hline 7 & 9 & 4 & 20 & 10 & 6 \\
\hline 8 & 10 & 5 & 21 & 9 & 4 \\
\hline 9 & 10 & 5 & 22 & 8 & 6 \\
\hline 10 & 11 & 6 & 23 & 10 & 7 \\
\hline 11 & 9 & 5 & 24 & 8 & 5 \\
\hline 12 & 8 & 6 & 25 & 11 & 7 \\
\hline 13 & 18 & 5 & - & & \\
\hline
\end{tabular}

The test- $t$ to find the value of $t$-count uses the formula:

$$
\mathrm{t}=\frac{\bar{X}_{1}-\bar{X}_{2}}{\sqrt{\frac{S 1^{2}}{n 1}+\frac{S 2^{2}}{n 2}}}
$$

The next step is determining a standard deviation with the symbol $S$ because it is necessary to find the value of standard deviation (S) count previously for seeing the value of $t$-count. The value $S_{1}$ is a standard deviation of the experiment group $\left(\mathrm{X}_{1}\right)$ and the value $\mathrm{S}_{2}$ is a standard deviation of the control one $\left(\mathrm{X}_{2}\right)$.

To find the value $S$ employs the formula:

$s=\sqrt{\frac{(n)\left(\sum X^{2}\right)-\left(\sum X\right)^{2}}{(n)(n-1)}}$

First: Counting $\mathrm{S}_{1}$ at $\mathrm{X}_{1}$

Counting the value $S$ is necessary to determine (1) the sum of the respondents (n), (2) the sum of $X_{1},(3)$ the sum of $X_{1}^{2}$, and score mean. It is known as follows: the sum of $n(25)$ the sum of $X_{1}(229)$ - the sum of $X_{1}^{2}$

$S_{1}=\sqrt{\frac{(25)(2353)-(229)^{2}}{(25)(25-1)}}$

$S_{1}=\sqrt{\frac{58.825-52.441}{600}}$

$S_{1}=\sqrt{\frac{6.3}{60}}$

$\mathrm{S}_{1}=\sqrt{10,64}$

$\mathrm{S}_{1}=3,26$

Second: Counting $\mathrm{S}_{2}$ at $\mathrm{X}_{2}$

Counting the value $S$ is necessary to determine: (1) the sum of the respondents (n), (2) the sum of $X_{2},(3)$ the sum of $X_{2}^{2}$, and score mean. It is known as follows: the sum of $n(25)-$ the sum of $X_{2}(135)$ - the sum of $X_{2}^{2}(753)$ - mean $\bar{X}_{2}$ (5.40)

$$
\begin{aligned}
& S_{2}=\sqrt{\frac{(25)(753)-(135)^{2}}{(25)(25-1)}} \\
& S_{2}=\sqrt{\frac{18.825-18.225}{600}} \\
& S_{2}=\sqrt{\frac{600}{600}} \\
& S_{2}=\sqrt{1} \\
& S_{2}=1
\end{aligned}
$$

Table 2: Experiment group $\left(\mathrm{X}_{1}\right)$ and Control group $\left(\mathrm{X}_{2}\right)$

\begin{tabular}{|c|c|c|c|c|c|c|c|c|c|}
\hline No & $\mathrm{X}_{1}$ & $\mathrm{X}_{1}{ }^{2}$ & $\mathrm{X}_{2}$ & $\mathrm{X}_{2}{ }^{2}$ & $\mathrm{No}$ & $\mathrm{X}_{1}$ & $\mathrm{X}_{1}{ }^{2}$ & $\mathrm{X}_{2}$ & $\mathrm{X}_{2}{ }^{2}$ \\
\hline 1 & 8 & 64 & 6 & 36 & 14 & 10 & 100 & 5 & 25 \\
\hline 2 & 8 & 64 & 5 & 25 & 15 & 10 & 100 & 5 & 25 \\
\hline 3 & 10 & 100 & 7 & 49 & 16 & 9 & 81 & 3 & 9 \\
\hline 4 & 8 & 64 & 5 & 25 & 17 & 11 & 121 & 5 & 25 \\
\hline 5 & 8 & 64 & 5 & 25 & 18 & 9 & 81 & 7 & 49 \\
\hline 6 & 8 & 64 & 5 & 25 & 19 & 7 & 49 & 6 & 36 \\
\hline 7 & 9 & 81 & 4 & 16 & 20 & 10 & 100 & 6 & 36 \\
\hline 8 & 10 & 100 & 5 & 25 & 21 & 9 & 81 & 4 & 16 \\
\hline 9 & 10 & 100 & 5 & 25 & 22 & 8 & 64 & 6 & 36 \\
\hline 10 & 11 & 121 & 6 & 36 & 23 & 10 & 100 & 7 & 49 \\
\hline 11 & 9 & 81 & 5 & 25 & 24 & 8 & 64 & 5 & 25 \\
\hline 12 & 8 & 64 & 6 & 36 & 25 & 11 & 121 & 7 & 49 \\
\hline 13 & 18 & 324 & 5 & 25 & $\sum \boldsymbol{X}$ & 229 & 2353 & 135 & 753 \\
\hline & & & & & $\bar{X}_{1}$ & 9,16 & - & - & \\
\hline & & & & & $\bar{X}_{2}$ & - & - & 5,40 & \\
\hline & & & & & $\mathrm{S}_{1}$ & 3,26 & - & - & \\
\hline & & & & & $\mathrm{S}_{2}$ & - & - & 1 & \\
\hline
\end{tabular}

The result: (1) mean $\left(\bar{X}_{1}=9,16\right)$ dan $\left(\bar{X}_{2}=5,40\right)$

(2) Standard deviation $\left(\mathrm{S}_{1}=3,26\right)$ and $\left(\mathrm{S}_{2}=1\right)$

The formula of $t$-test $=\frac{\bar{X}_{1}-\bar{X}_{2}}{\sqrt{\frac{S 1^{2}}{n 1}+\frac{S 2^{2}}{n 2}}}$

$\mathrm{t}=\frac{9,16-5,40}{\sqrt{\frac{3,26^{2}}{25}+\frac{1^{2}}{25}}}$

$\mathrm{t}=\frac{3,76}{\sqrt{\frac{10,62}{25}+\frac{1}{25}}}$

$=\frac{3,76}{\sqrt{0,46}}$

$\mathrm{t}=\frac{3,76}{0,68}$

$\mathrm{t}=5.529$

The value of $t$-count is 5.529 and the value of $t \alpha ;\left(\mathrm{n}_{1}+\mathrm{n}_{2}-2\right)$ or the value of $t$-table $\left(\mathrm{t}_{0,05 ; 48}\right)$ is 1.645 . The value of $t$-table with a deviation level achieves $5 \%$ of the 50 respondents included in the critical cell at 1.645 . It means that if the value of $t$ count is lower than the value of $t$-table, $\mathrm{H}_{0}$ is confirmed, but $\mathrm{H}_{1}$ is rejected. In contrast, if the value of $t$-count is higher than t-table, $\mathrm{H}_{0}$ is rejected. $\mathrm{H}_{1}$ is confirmed. In the study, the value of $t$-count is 5.529 and the value of t-table is 1.645 . Thus, the value of $t$-count is higher than $t$-table. Thus $\mathrm{H}_{\mathrm{o}}$ is rejected, but $\mathrm{H}_{1}$ is confirmed. It can be concluded that the learning of exposition text writing with sequential jigsaw method is more effective than conventional one.

\section{Leearning Model of Exposition Text Writing with Jigsaw Method}

The learning model development of exposition text writing with sequential jigsaw method consists of six activities: (1) conditioning, (2) operating/ writing sequentially, (3) discussing, (4) presenting, (5) writing independently for producing a full text, and (6) scoring.

\section{First: Conditioning}

Steps:

a. Teachers make a heterogeneous group of 5-6 students

b. Teachers make the seats in cycle

c. Teachers distribute sheets of papers to students 


\section{International Journal of Science and Research (IJSR) \\ ISSN (Online): 2319-7064}

Index Copernicus Value (2013): 6.14 | Impact Factor (2014): 5.611

d. Teachers ask each student to write his or her friends in his or her group: number 1 is his her own name, number 2 is his or her friend's name at the right hand, number 3 and so forth are also the same. All the students in a group have written the names.

Second: Operating/writing sequentially

Steps:

a. All the students of number 1 are asked to write a first sentence on a sheet of paper

b. After that, the sheet of the paper is given to his or her friend of number 2 at the right. Then, he or she is asked to write the next sentence his or her second friend.

c. After that, the sheet of the paper is given his or her friend of number 3 at the right hand. Then, he or she is asked to write the next sentence.

d. Next, the sheet of the paper is given to his or her friend of number 4 at the right hand. Then, he or she is asked to write the next sentence.

e. After that, the sheet of the paper is given his or her friend of number 5 at the right hand. Then, he or she is asked to write the next sentence.

\section{Third: Discussion}

In the discussion activity in an internal group, the instructional materials have been determined by a teacher. If a group consists of 5 students, the materials covers five Discussion Items (DIs). For example, DI 1: Text Title, DI 2: Text Content, DI 3: Spelling Uses, DI 4: Vocabulary/ Diction Uses, and DI 5: Cohesion and Coherence of Text. The five discussion items are contained in a text sequentially written by 5 students. After that, the teacher appoints a discussion coordinator in an internal group at each DI. For example, student $\mathrm{A}$ in a group serves as a coordinator of DI 1, student $\mathrm{B}$ as a coordinator of DI 2 , students $\mathrm{C}$ as a coordinator of DI 3 , student D as a coordinator of DI 4 , and student as a coordinator of DI 5. If there is a problem with an instructional material, a student can ask a question to his or her teacher as a facilitator. The false discussion materials will be revised and they will be written at the bottom of the text. In the discussion, there is no expert. All the members can give an idea or opinion.

In the conditioning stage, teachers prepare all facilities so that a learning process of exposition text writing will be running well. They explain an instructional material comprehensively. After that, they make the heterogeneous groups of 5-6 students for each. It is based on their creativity. After making the groups, they ask the students to join in their group and take a seat in cycle. Then, they distribute the sheets of papers to each student, and the students are asked to write their: number 1 is his or her own name, number 2 and so forth are the members' names beginning with them at the right hand.

\section{Fourth: Presenting}

The presenting activity, each internal group presents a discussion result. The important points are presented by a group. As a coordinator of the group, he or she presents his or her internal discussion result in the discussion class. An idea and suggestion of the other groups are written as reviewing. All the discussion activities are monitored by a teacher as a facilitator. Any questions and false answers will be corrected and reviewed by the teacher with argumentations and explanations. The members of the groups will revise them based on the other group members' and teachers' ideas and suggestions. In the activity, the students take an active part in the class discussion. It makes the students think critically and develop their questioning/ speaking skill.

\section{Fifth: Writing independently}

An exposition text in a paragraph has been revised after the presenting activity. Afterwards, each student is asked to give one sheet of paper containing an exposition text in a paragraph to the student of number 1 . In the activity of writing independently, a teacher gives an assignment to each student to write one another paragraph with the title into a complete exposition text. The assignment can be completed as homework, but the students are not permitted to change the first paragraph. After finishing the text, they are asked to give to their teacher to be evaluated.

\section{Sixth: Scoring}

The result of the exposition text (full text) is corrected by his or her teacher for scoring. The scoring system is based on the substantial exposition text, language structure, paragraph development, cohesiveness, and coherence among sentences in a paragraph or between paragraphs in a text. A good text will be graded with a high score and displayed at a school text board or published at a school bulletin. The learning steps of exposition text writing with sequential jigsaw method can develop an instructional material comprehensively.

\section{Conclusion}

a. Evaluating a model at SMA Negeri 1 State Senior High School, Karanganyar regency for 25 students as an experiment group (getting treatment) and at SMA Negeri 2 State Senior High School, Karanganyar regency for 25 students as a control group (no getting treatment). In the model, it is found as follows: the experiment group at $76 \%$ and control one at $45 \%$. Thus, the experiment group is higher than the control one.

b. Counting the statistic with $t$-test states that the learning of exposition text writing with sequential jigsaw method is more effective than conventional one. It is indicated that the value of $t$-count (5.529) is higher than $t$-table (1.645). Thus, $\mathrm{H}_{0}$ is rejected, but $\mathrm{H}_{1:}$ is confirmed = (the learning of exposition text writing with sequential jigsaw method is more effective than conventional one).

c. The learning model development of exposition text writing with sequential jigsaw method consists of six activities: (1) conditioning, (2) operating/ writing sequentially, (3) discussing, (4) presenting, (5) writing independently for producing a full text, and (6) scoring/evaluating.

\section{References}

[1] Chalmers D dan Fuller R, 1999, Research and a Professional Development Programme on Teaching 
Learning Strategies as Part of Course Content, International Journal for Academic Development, (4)1, 28-32.

[2] Arends, Richard I, 2008, Learning to Teaching (Edisi Terjemahan Buku Satu: Belajar untuk Mengajar). Penerjemah Helly Prajitno Soetjipto dan Sri Mulyantini Soetjipto, Yogyakarta: Pustaka Pelajar.

[3] Joyce, Bruce, 2011, Models of Teaching (Model-Model Pengajaran). Translated in Indonesian by Achmad Fawaid dan Ateilla Mirza, Yogyakarta: Pustaka Pelajar.

[4] Andayani, 2015, Problema dan Aksioma dalam Metodologi Pembelajaran Bahasa Indonesia, Yogyakarta: Deepublish.

[5] Westwood, Peter, 2008, Teaching Methods: What Teachers Need to Know About, Australia: Acer Press.

[6] Kadir, Suhaida Abdul; Wong, Su Luan; Zaidatol Akmaliah Lope Pihie; Yaacob, Noran Fauziah; et al. 2005. The Effects of Cooperative Learning Strategy on Peer Attachment. Pakistan Journal of Psychological Research: 20, 3/4; ProQuest Research Library, p. 121.

[7] Achmad H.P. and Alex Abdullah, 2013, Linguistik Umum, Jakarta: Erlangga.

[8] Beaugrande, Robert-Alain de dan Wolfgang Ulrich Dressler, 1981, Introduction to Text Linguistics, USA: Longman.

[9] Brown, Gillian, and George Yule. Discourse analysis. Cambridge University Press, 1983.

[10] Mahsun. 2014, Teks dalam Pembelajaran Bahasa Indonesia Kurikulum 2013, Jakarta: PT RajaGrafindo Persada.

[11] Keraf, Gorys, 2001, Komposisi, Ende Flores: Nusa Indah.

[12] Bulger, Sean M., Derek J. Mohr, and Richard T. Walls. "Stack the deck in favor of your students by using the four aces of effective teaching." Journal of Effective Teaching 5.2 (2002).Gall, M.D., J.P.

[13] Gall, dan W.R. Borg, 2003. Educational Research: An Introduction (Seven Edition), Boston: Pearson.

[14] Sugiyono, 2010, Metode Penelitian Pendidikan: Pendekatan Kuantitatif, Kualitatif, dan $R$ \& $D$. Bandung: Alfabeta.

[15] Budiyono. 2009. Statistik untuk Penelitian (Edisi ke-2), Surakarta: Sebelas Maret University Press.

\section{Author Profile}

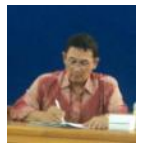

Yakub Nasucha received a Master degree in Linguistics from Universitas Sebelas Maret Surakarta. His focus of study is in language teaching, specially Indonesian language teaching at schools. $\mathrm{He}$ is currently a full-time teaching staff at Indonesian Department of Universitas Muhammadiyah Surakarta and is now pursuing a Doctoral degree from Universitas Sebelas Maret.

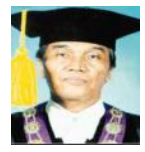

Haris Mudjiman received the B.S. in Geographical education from Yogyakarta State University and an M.A. degree in Population study from University of Hawaii-Honolulu. Also, he received a Ph.D. in higher education from University of California Berkeley in 1981. He is now a Professor of higher education in Universitas Sebelas Maret, Surakarta. 